\title{
Filosofia e Religião na Grécia: Dinâmica de Ruptura e Diálogo
}

\author{
Sally C. Humphreys \\ University College, Londres
}

HUMPHREYS, S. C. Filosofia e religião na Grécia: dinâmica de ruptura e diálogo. Classica, Belo Horizonte, 3:8-36, 1990.

\begin{abstract}
One aspect of the problem we have been asked to examine can be formulated in the question: how does it come about, in the 'axial age', that men start to ask whether human social organization and political decisions should be dominated by religious imperatives, and start to compare the claims of differing religious and/or secular accounts of the cosmos. What I propose to do in this paper is to look at the dynamics of this process by analysing the impact on Greek (and especially Athenian) religious thought and practice, and on poetry, of the pressures towards secularization and rationalization wich we can discern in Greek culture in the period between c. 550 and 300 B. C.
\end{abstract}

UNITERMS: Ancient Greek Religion Ancient Greek Philosophy. Ancient Greek Anthropology.

\section{Introdução: da dóxa à opinião}

O problema que pretendo examinar pode ser expresso através da seguinte pergunta: como, na idade axial, acontece que se comece a indagar se a organização social humana e as decisões políticas devem ser dominadas ou não pelos ditames religiosos - e se comece a comparar as alegações de diferentes religiões entre si ou com explicações seculares relativas ao cosmo? O que proponho, neste artigo, é examinar a dinâmica de tal processo, através da 
análise do impacto, nas concepções e nas práticas religiosas dos gregos antigos, bem como em sua poesia, de pressões em favor da secularização e racionalização, as quais podem ser percebidas, especialmente em Atenas, no período que vai de 550 a 300 a. C.

O movimento em direção à secularização começa, na Grécia arcaica, com uma tendência para a eliminação do sobrenatural no âmbito das decisões políticas, o que acarreta o desenvolvimento de normas de procedimento cada vez mais sofisticadas e formalmente racionais, envolvendo processos de votação e acordos sobre a partilha do poder: a eunomía espartana incluía mesmo a redistribuição da terra em parcelas iguais. As referências ao sagrado não foram contudo inteiramente eliminadas, embora a influência de videntes e adivinhos (que talvez nunca tenha sido muito grande) tenha diminuído. Seja como for, a elite política mantinha amplo controle sobre os processos de consulta aos deuses, através da utilização dos oráculos de santuários localizados fora dos limites da cidade, os quais podiam ser manipulados, dando margem, quando ambíguos, a acalorados debates sobre as interpretações possiveis.

A experiência de uma ordem social regular e racional ${ }^{1}$ deve ter contribuído para o desenvolvimento, no século VI a. C., de uma nova visão do cosmo que enfatizava a simetria e a regularidade dos processos naturais e criticava a concepção então vigente dos deuses antropomórficos. O fato de a autoridade religiosa estar apenas precariamente estabelecida favoreceu a radicalização da polêmica, pois era permitido aos poetas apresentar, em suas obras, versões divergentes a respeito dos deuses e do mundo. A ausência de autoridade religiosa fez também com que a reação defensiva contra a nova visão secular do mundo fosse difusa, não se concentrando em nenhum grupo específico. Esta primeira versão do debate entre religião e ciência foi, em grande parte, internalizada pelos pensadores gregos, em vez de levar à cristalização de grupos de poder que competissem uns com os outros.

1

Humphreys 1978, cap. 9-10. Não enfatizaria aqui a influência de Delfos sobre c desenvolvimento do pensamento político e das instituições gregas, mas antes as inovações ocorridas em diversas cidades-estado e os efeitos decorrentes da interrupção, pelos tiranos, tanto do desenvolvimento rumo a formas mais regulamentadas de partilha do poder quanto, a fortiori, do processo de conscientização da elite sobre o valor da lei e da ordem. 
A importância do legado cultural arcaico, cujas concepções referentes ao cosmo e às relações entre homens e deuses eram até então inquestionáveis, diminuiu. $\mathrm{Na}$ época dos sofistas assumia-se, em larga escala, uma opinião diferente com relação à doxa não reflexiva, para usar a terminologia de Bourdieu (1977). E significativo que a consciência da existência de diferentes visões do mundo não tenha sido acompanhada de qualquer tentativa específica, por parte das escolas ou seitas, no sentido de definir suas doutrinas e ortodoxias. Assim se entende que a expressão característica do pensamento religioso na idade clássica seja, de um lado, as tragédias produzidas pelos poetas atenienses num ambiente de livre competição pública e, por outro lado, as doutrinas dos cultos esotéricos, protegidas do confronto aberto por regras de sigilo mas incapazes de exigir dos iniciados uma devoção exclusiva. A disputa dava-se também entre filósofos, médicos e historiadores, resultando, em alguns casos, na institucionalização de escolas rivais.

Em termos gerais, portanto, a elite intelectual agia de modo individualista, com pouca organização formal. Os pitagóricos, organizados em comunidades que compartilhavam crenças e um modo de vida específico (Burkert 1972), constituíam exceção. O clima geral de disputa entre sistemas produzidos por indivíduos identificáveis (cuja visão de mundo podia, em alguns casos, sofrer modificações e desenvolver-se ao longo do tempo) favoreceu o surgimento de uma atitude relativista, bem como a difusão do interesse por questões de metodologia e pela discussão de critérios segundo os quais se pudesse julgar uma abordagem superior a outra. Do mesmo modo, desenvolveu-se a tendência de considerar os problemas relativos ao sentido da vida como algo a ser resolvido individualmente, usando-se a própria criatividade ou sintetizando as diversas visões de mundo disponíveis.

Claras demarcações de gênero e contexto serviam, entretanto, para evitar que concepções opostas sobre a sociedade e o cosmo se confrontassem abertamente: criticar a democracia ateniense numa tragédia, numa comédia ou num trabalho historiográfico ou filosófico era diferente de propor reformas na constituição durante uma assembléia.

E contra esse pano de fundo do pluralismo intelectual, que persiste ao longo de toda Antigüidade clássica, que se deve consi- 
derar o judaísmo, o islamismo e o cristianismo. O que deu a essas religiões considerável força foi juștamente seu monoteísmo intolerante, combinado com a origem em grupos étnicos ou em classes sociais relativamente homogêneos, distantes dos centros institucionais de poder, tornando possivel o desenvolvimento de sistemas de organização e de liderança próprios. ${ }^{2}$ Com efeito, é preciso examinar mais detalhadamente a situação da religião na Grécia antiga para poder-se entender a tensão entre Igreja e Estado na Antiguiidade e, dentro da Igreja, a tensão entre orientação temporal e extra-temporal.

A crítica racionalista das crenças tradicionais provocou reações contraditórias: por um lado, procurou-se racionalizar o mito, a teologia e o culto; em contrapartida, valorizavam-se deliberadamente os tipos de experiência religiosa tidos mais claramente como irracionais ou como capazes de estender-se além dos limites do pensamento racional. Essa sutil atração pela irracionalidade teria sido, em minha opinião, historicamente condicionada. Apesar de Dodds (1951) a ter considerado, em termos freudianos, como exemplo de processo psíquico universal - uma forma de reação previsível gerada pela ansiedade reprimida no processo de dominação cada vez maior da cultura grega pelo pensamento racional - prefiro dar ênfase à construção de um conceito do irracional pelos próprios gregos. Com efeito, novas fronteiras foram estabelecidas entre os processos e sistemas racionais, de um lado, e os irracionais, de outro. Tal demarcação de limites institui assim suas próprias tensões, atribuindo-se ao irracional tanto valores positivos quanto negativos. Como acontece com relação à demarcação de limites entre a vida pública e privada na Grécia (cf. Humphreys 1983), o estudo do contexto histórico no qual foi inicialmente formulada a oposição entre racional e irracional, ainda hoje de fundamental importância para a cultura ocidental, pode ajudar no desvelamento de algumas das tensões e ambiguiidades que continuamos a experimentar.

2

E claro que os monoteístas podem estar também tão intimamente engajados num diálogo com visões de mundo opostas quanto outros cuja atitude seja mais tolerante; cf. Murray 1925, cap. 5 e Liebeschuetz $1979: 252-277$, sobre as similaridades entre pensamento pagão e cristão nos séculos III-IV d. C. A diferença reside no esforço feito pelos líderes monoteístas no sentido de controlar as crenças de seus seguidores. 
Ora, uma das características mais marcantes desse contexto é a familiaridade entre os debatedores. Embora os porta-vozes da revolução intelectual grega fossem dados à polêmica, não eram estruturalmente diferentes daqueles a quem criticavam. Filósofos e médicos relacionavam-se com poetas e políticos: Péricles era amigo de Anaxágoras; Sófocles lia Heródoto; Eurípedes e Aristófanes conheciam as idéias dos sofistas e de Sócrates; Licurgo era discípulo de Platão. Os filósofos, médicos e historiadores viviam rodeados de gente que escrevia poesia, que exercia importantes funções nos rituais religiosos, que ia aos templos para curar-se, que assistia a tragédias, que patrocinava a introdução de novos cultos na cidade. Toda essa gente conhecia a crítica dos racionalistas, dirigida não apenas contra as superstições populares: as referências a ela, no teatro, mostram que se supunha que o conjunto do público tivesse conhecimento das novas idéias. Ésquilo, Sófocles e Eurípedes, por exemplo, fazem referência à noção de que Apolo seria uma personificação do sol; do mesmo modo, na $P a z$ de Aristófanes, um escravo observa: "dizem que nos transformamos em estrelas quando morremos". As novas teorias penetravam em todos os setores da sociedade.

$O$ ataque dirigido contra as crenças tradicionais pelos que escreviam em prosa - filósofos, historiadores e médicos - tornou-se radical no final do século VI e no século V. Afirmava-se ser ridículo o que os poetas haviam dito sobre os deuses. Quem poderia acreditar que eles se ferissem em batalhas, se flagrassem uns aos outros em adultério ou se apaixonassem por humanos? Por que se haveria de supor que os deuses tivessem formas e paixões humanas? A ser assim, os cavalos, se tivessem deuses, também os imaginariam como cavalos. As declarações dos poetas a respeito do passado, por sua vez, eram consideradas exageros, apresentando um grande número de fenômenos nunca experimentados pela memória viva da cultura: cavalos falantes, rios guerreiros, homens que brotam da terra já adultos (Detienne 1981, cap. 4). $\mathrm{O}$ ataque à tradição oral do povo não é menor: Hecateu de Mileto começa seu livro de Genealogias com o brusco comentário de que "as histórias contadas pelos gregos são muitas e ridículas". Tucídides, por seu lado, criticava os ateniensés por não saberem como 
havia terminado a tirania de Pisístrato e de seus filhos. Os médicos igualmente zombavam da ignorância dos sacerdotes que davam conselhos medicinais, bem como dos curandeiros e dos pacientes comuns. ${ }^{3}$

A nova concepção leiga do cosmo, da sociedade e da razão proposta por esses críticos da tradição era empirista - o conhecimento deve derivar da observação direta dos fenômenos ou de teorias análogas a processos observáveis (Heráclito B 55 D-K; Lloyd 1966 e 1979). O novo modelo era também político: a vida pública tornava-se cada vez mais diferenciada em relação à vida privada, enfatizando-se a superioridade da primeira; a vida pública era mais ordenada, mais racional e mais importante que a vida privada (Humphreys 1983). Finalmente, o novo modelo era lógico: a busca de clareza de raciocínio e a habilidade em derrotar os oponentes numa argumentação era enfatizada tanto na filosofia e na ciência quanto nas assembléias, nos conselhos e nos tribunais.

Contra esse ataque tripartido - baseado na ênfase do empirismo, na primazia da vida pública e na necessidade de argumentação lógica - a poesia e o pensamento religioso reagem de dois modos: ou modificando as crenças tradicionais, de modo a torná-las menos vulneráveis ao ataque, ou fazendo virtude justamente daquilo que se apontava como defeito. Assim, em atenção à ênfase do empirismo, tentou-se racionalizar os mitos e histórias sobre os deuses, expurgando-os dos elementos miraculosos e indignos, bem como ressaltando residuos verossímeis de fatos históricos ou de afirmações alegóricas sobre fenômenos naturais. Por outro lado, contudo, desenvolveram-se também concepções mais abstratas da divindade, a fim de que, considerados os deuses como incorpóreos, não se pudesse contestar empiricamente sua existência.

Em relação à ênfase da vida pública, o culto oficial dos deuses foi racionalizado de diversas maneiras: as cerimônias mais arcaicas e excêntricas tornaram-se menos relevantes, enquanto os benefícios a serem esperados em retribuição pela execução dos ritos foram salientados. Trata-se, nesse caso, de benefícios imediatos, advindos

3

Cf. Lloyd $1979: 15-21,26-29$. As criticas trocadas por médicos rivais eram igualmente contundentes. 
da distribuição ao povo da carne das oferendas; mas também de bênçãos dos deuses, cujas invocações traduziam essa esperança, como nos exemplos de Zeùs Sotér (Zeus Salvador) ou Athenà Hygieía (Atena que dá saúde). O povo refletia sobre a função social das festas religiosas, entendidas como instrumentos de socialização de efeito "civilizador" (Platão, Leis 738, 828; Políbio IV, 20-1; cf. Borgeaud 1979). Simultaneamente, contudo, outros aspectos da vida religiosa passaram a ser explicitamente relacionados com a vida privada, envolvendo mulheres e crianças, e com espaços não políticos: florestas, montanhas e locais sagrados de regiões remotas.

Finalmente, em resposta às exigências do pensamento lógico, observa-se tanto uma influência dos modelos científicos sobre doutrinas religiosas - o que começa com o orfismo e se estende até a astrologia e a magia helenística - quanto uma ênfase deliberada no papel do irracional na experiência humana, sob a forma de inspiração poética ou nos estados de transe, possessão e êxtase.

São essas três formas de reação, cada qual ambígua em si mesma, envolvendo tanto a aceitação quanto a rejeição da crítica racionalista, que desejo discutir mais detalhadamente a seguir.

\section{O material e o imaterial}

No caso da reação contra o empirismo, torna-se particularmente evidente que nem sempre se pode distinguir com precisão os que atacam as crenças tradicionais dos que as defendem (cf. Lloyd $1979: 39-46$ ). Com efeito, os próprios filósofos e historiadores elaboram interpretações racionalizadas dos mitos a par de concepções abstratas dos deuses, enquanto os poetas órficos e tragediógrafos incorporam idéias "filosóficas" em suas obras.

Os mitos sobre os heróis, ern especial, foram logo submetidos a esse processo de racionalização e viram-se transformados em narrativas históricas a respeito de reis verdadeiros, as quais teriam sido deformadas, ao longo do tempo, pelo exagero dos poetas (Veyne $1983: 52 \mathrm{ss} ; 70 \mathrm{ss}$ ). Quanto às lendas relativas aos deuses, Evêmero, no início do terceiro século, estende também a elas este tipo de abordagem, afirmando que eles teriam sido apenas poderosos mortais que se teriam deificado a si próprios (como, de resto, certos reis faziam naquele tempo; Meijer 1981). A reação 
inicial, contudo, antes do terceiro século, foi no sentido de humanizar os heróis e, opostamente, desumanizar os deuses, transformando-os em forças físicas ou psíquicas. A própria religião grega já dava, de antemão, margem a isso: Zeus era o trovão e a habilidade da mente em controlar e manipular (métis); Afrodite era a força psíquica do amor; Poseidon provocava ondas no mar e terremotos.

O contexto apresentava-se de tal modo intrincado que, no século VI, quase não se pode distinguir os novos movimentos religiosos de algumas das novas filosofias, ou melhor, só se pode distingui-los em vista do desenvolvimento ulterior de cada corrente. O pitagorismo e as idéias e práticas associadas ao nome de Orfeu tinham muito em comum. A maior diferença entre os dois parece ter sido o fato de que os pitagóricos se organizavam em comunidades, enquanto parece que os mestres órficos agiam de um modo mais independente, com pouco compromisso em relação aos grupos que a eles acorriam buscando iniciação (West $1983 \mathrm{a}$ ). Apesar disso, ambas correntes ofereciam um novo tipo de conhecimento a respeito da outra vida e ensinavam novas teorias sobre a natureza do universo, as quais tinham um tom mais "científico" do que o das cosmologias tradicionais. ${ }^{4}$ Ambas enfatizavam, tanto em seus ensinamentos quanto nas regras dietéticas que os acompanhavam, a separação entre os crentes e o resto do mundo, isto é, os não iniciados. Ambas rejeitavam o sacrifício de animais, rito principal do culto tradicional. ${ }^{5}$ Os mestres órficos, à semelhança dos médicos hipocráticos, advertiam seus ouvintes do perigo que

4

Cf. West 1963 , a respeito da contribuição de $\vec{A}$ lcman no que diz respeito ao desenvolvimento de uma cosmogonia mais «fisiológica». 5

Detienne $1972: 76-114 ; 1979$. Como Kirk (1981) salienta, já Hesíodo considerava o sacrificio de animais problemático (pelo fato de os fiéis consumirem a carne). Os Dipóleia que, na forma que conhecemos, isto é, envolvendo o tribunal de justiça no Pritaneu, não devem ser anteriores ao século VII, talvez expressem a inquietação existente com relação ao sacrifício de animais nos rituais (cf. o relato sugestivo, mas não inteiramente satisfatório, em Burkert $1972 \mathrm{~b}: 153-161)$. E surpreendente que a principal corrente da tradição filosófica pareça ter pouco a dizer sobre o sacrifício de animais até o momento em que Teofrasto apresenta argumentos contra o mesmo em seu Peri eusebeias (cf. Bernays $1866: 129-131$; Pötscher 1964; verificar também Platão, Leis 782 c). A história da repugnância crescente pelo sacrifício de animais, que já antes do século IV d. C. tinha-se propagado mesmo entre os pagãos, precisa ninda ser estudada. 
corriam ao se entregarem nas mãos de charlatães, os quais careciam de conhecimento verdadeiro e só tinham interesse em enriquecer (Burkert 1982) .

Na trilogia Licurgo, de Êsquilo, Orfeu aparece adorando o sol, que seria o próprio Apolo, idéia buscada pelo autor, provavelmente, em alguma cosmologia órfica (West $1983 \mathrm{a}-\mathrm{b}$ ) e mencionada ainda diversas vezes em outras tragédias. Na $P a z$, de Aristófanes (412), diz-se que o sol, a lua e as estrelas têm esperança de que os gregós passem a oferecer sacrifícios a eles, deixando de adorar os deuses. Platão, no Crátilo (397 c-d), atribui a Êutifron, especialista em religião, a opinião de que o homem primitivo adorava os corpos celestes. O sofista Pródico, no $\mathrm{V}$ século, dizia que as concepções tradicionais a respeito dos deuses tinham surgido porque "o homem primitivo deificava os frutos da terra e praticamente tudo que contribuísse para sua existência" (Henrichs 1975; P. Herc. 1428 fr. 19). Eurípedes, por sua vez, faz com que Tirésias tenha uma opinião semelhante nas Bacantes (274-285). Como se vê, os mitos sobre os deuses eram entendidos de forma alegórica tanto por filósofos quanto por poetas, tendo mesmo Metrodoro de Lâmpsaco, um discípulo de Anaxágoras, supostamente interpretado os poemas homéricos como alegorias sobre os processos naturais. ${ }^{16}$

Outras interpretações alegóricas tinham caráter menos agressivamente materialista. O próprio Anaxágoras interpretou os poemas homéricos como alegorias sobre a virtude e a justiça, enquanto Ésquilo, ao que parece, concebia suas próprias tragédias do mesmo mođo (Humphreys 1975). A técnica de interpretação alegórica permitia aos poetas argumentar que suas obras continham verdadés não imediatamente captáveis, sendo tais alegações freqüentemente expressas em linguagem deliberadamente obscura, numa época em que a prosa começava a se impor como alternativa para a poesia.

Atribui-se a Ẽsquilo a escolha intencional de um estilo altamente poético, como forma de enfatizar a gravidade (semnótes) de sua mensagem. De modo semelhante, Píndaro adota um estilo com

Richardson 1975; note-se que este processo de alegorização já vinha. sendo utilizado pela tradição órfica antes do século IV a. C., como mostra o papiro de Derveni (West 1983 a). Sobre alegorias naturalistas em Esquilo, ver frags. 105, 125 Mette (1959). 
características que lembram as do oráculo de Delfos, usando imagens enigmáticas ${ }^{7}$ que sugerem um significado oculto, como "áriston mèn hydor" - "excelente a água" (Olímpicas 1); "há um tempo em que o homem tem necessidade de ventos, outro de chuva" (Olímpicas 11) . O mesmo poeta vale-se ainda de frases gnômicas como as famosas máximas de Delfos: "conhece-te a ti mesmo" e "nada em demasia" - cuja decifração ficava a cargo do leitor, de acordo com sua própria experiência de vida. Através desses recursos podia o poeta, sutilmente, advertir seus clientes célebres de que eram apenas mortais e de que deviam aspirar à virtude tanto quanto ao sucesso, falando de maneira indireta e sem ofendê-los (cf. Baquílides III, 85-7) .

Tal alegação de que verdades profundas só podiam ser expressas indiretamente, em linguagem poética oracular ou alegórica, encontrava algum suporte no fato de os filósofos experimentarem dificuldades em expressar com palavras as novas concepções abstratas que vinham desenvolvendo sobre a divindade. Deve-se ressaltar que a rejeição total da crença nos deuses e no conteúdo dos mitos era muito rara no mundo antigo (e mesmo, não se registrava de modo algum, afirmariam alguns) ${ }^{8} \mathrm{O}$ que se rejeitava era a concepção antropomórfica dos deuses, isto é, o entendê-los como homens de características sobrenaturais. Tales dizia: "tudo está cheio de deuses". Xenófanes, por sua vez, afirmava que "há um só deus, diferente dos homens: todo ele vê, todo ele pensa, todo ele ouve". Para Anaxágoras, no século $\mathrm{V}$, deus era nô̂s, intelecto, o criador

7

Sobre o papel da comunicação por enigmas e sobre sua decifração no pensamento grego arcaico, ver Veyne 1983:41-2; tanto a crença em presságios quanto o uso de oráculos encorajavam essa atitude. Atentar para a paródia da linguagem enigmática dos oráculos em Aristófanes, Paz 1065 ss. Os deuses, quando não se comunicam por sinais, tendem a proferir oráculos em versos. Isso talvez tenha encorajado os poetas a dar um tom «oracular» a sua poesia Deve-se notar o gosto de Esquilo por metáforas. Sobre o uso que Pindaro faz da distância entre os mortais contemporâneos e o mundo heróico do mito, seja para bajular seus clientes, seja para manter a dignidade de sua própria posição, ver Veyne $1983: 30-31$.

8

Mito: Veyne 1983; Dodds 1937 (1973, 96-7). Ausência de ateísmo: Meijer 1981; Bremmer 1982; sobre o Sísifo de Criticas: Dihle 1977. Contra, Henrichs 1975. E certo que os gregos antigos classificavam alguns pensadores como átheoi, acusando-os de não acreditarem nos deuses e de persuadirem nas Thesmohoriázousai de Aristofanes: 443-458) e, às vezes, tomando medidas contra os incrédulos (Momigliano 1973; Dodds 1975). 
das relações lógicas que os filósofos estavam descobrindo no universo. Do mesmo modo, o daimónion de Sócrates é chamado por um termo vago que, deliberadamente, não caracteriza uma personagem particular. Para Platão, deus, a suprema causa do cosmo, existe num plano inteiramente imaterial, num mundo de formas puras, análogo ao da matemática.

Conforme Platão, a educação deveria ser um processo gradual de iniciação, através da qual o filósofo pudesse chegar a uma experiência mais direta desse plano imaterial da existência, que não pode ser descrito em termos inteligíveis para não iniciados. Só um mito ou uma alegoria pode dar uma vaga indicação sobre sua natureza. Desse modo, a interação do pensamento religioso com o filosófico produz uma crescente convergência entre as concepções sobre as transformações psicológicas geradas pela experiência do filósofo e as promessas de revelação de um novo significado da vida, oferecidas pelas religiões de mistérios. Tal convergência só atinge sua plena realização nos textos gnósticos e neoplatônicos da era imperial mas, desde o início, há uma afinidade potencial entre o empenho dos filósofos em expressar uma concepção nova, mais abstrata e "inefável" da divindade, e o silêncio que os iniciados tinham de guardar com respeito ao conhecimento secreto por eles recebido na "revelação" dos mistérios. A doutrina revelada nos mistérios de Elêusis era, até onde sabemos, mais materialista que abstrata. A regra do sigilo resguardava os ritos da crítica racionalista, criando um espaco protegido no qual se podia dar a experiência mística. No contexto da atmosfera crítica que então prevalecia, esse silêncio protetor era importante (cf. Lloyd 1979 : 228-9, com relação à analogia com as práticas médicas) .

$\mathrm{Na}$ tragédia do século $\mathrm{V}$ pode-se perceber a crescente diferença entre os mortais e os deuses, decorrente da nova concepção desmaterializada destes (Veyne $1983: 52-70 \mathrm{ss}$ ), o que, eventualmente, se concretiza, em Platão, através da idéia de que o próprio homem se divide numa parte divina - a alma - e numa mortal, animal - o corpo. No teatro, os deuses homéricos, benfeitores e protetores de seus prediletos, desaparecem. Somente Apolo e Atena, nas Eumênides de Esquilo, têm ainda alguma semelhança com o modelo homérico. Mas mesmo estes revelam a influência, sobre Êsquilo, 
do processo de racionalização das instituições políticas, bem como das idéias filosóficas a respeito dos mecanismos regulares e imutáveis que operam no mundo natural: Atena cria a instituicão pela qual a ordem é mantida na cidade, o tribunal do júri; Apolo representa o princípio de organização social baseado explicitamente na biologia (a patrilinearidade).

Já com relação às peças de Sófocles, os deuses participam diretamente da ação apenas no $\bar{A} j a x$, em que Ulisses se horroriza diante dos atos de sua benfeitora divina, Atena. Em geral, contudo, os comentários do coro apresentam uma visão filosófica dos deuses apenas remotamente relacionada com a ação - especialmente na famosa ode sobre o poder do amor, na Antigona. ${ }^{9}$ Os deuses de Eurípides, por seu turno, são perigosos, incompreensíveis e estranhos. Viver em associação íntima com os deuses implica distanciamento da vida política normal, como ocorre no caso da inversão radical da normalidade pelas bacantes, no prolongamento exagerado da adolescência de Hipólito, em consequiência de sua devoção a Ärtemis, ou no pacífico isolamento do menino Íon no templo de Apolo em Delfos.

Eurípides separa a ação e o coro de forma ainda mais forte que Sófocles. Com freqüência, sórdidas manobras políticas são interrompidas por interlúdios líricos, nos quais o coro parece retratar a vida em outro plano, apresentando uma existência idílica em que a beleza do mundo natural se confunde com as glórias perdidas do mundo mítico dos heróis. Terminando suas peças com referências a ritos religiosos, através dos quais as ações representadas eram continuamente relembradas, Eurípides estabelece a ligação desse tempo de sonhos com o tempo e o espaço reais (ver Foley 1985). Simultaneamente, considerando o realismo pouco lisonjeiro com que as ações dos heróis são frequientemente retratadas, tais referências aos ritos evidenciam a natureza problemática da relação da vida secular com a vida religiosa.

9

Cf. a ode do coro do Agamêmnon de Ésquilo (160-183), juntamente com os comentários de Smith 1980. No Édipo de Sófocles, o conhecimento absoluto de Tirésias sobre o passado, o presente e o futuro torna a personagem um representante do plano divino da existência, embora não possa ele explicar os fatos que revela nem mudá-los. O colapso na comunicação entre o mesmo e Edipo é, num certo sentido, paradigma da condição humana em geral. Os deuses agem sobre os homens, não mais interagem com eles. 


\section{Salvação pública e privada}

Gostaria de continuar abordando a obra de Eurípides, que constitui fonte extraordinariamente rica para o estudo das idéias muitas vezes contraditórias dos pensadores religiosos do período clássico. Em primeiro lugar, contudo, desejo examinar o modo como a reação à crítica filosófica afetou a prática religiosa de então.

A codificação das leis, feita por Sólon, o fim da tirania de Pisístrato e as guerras médicas marcam, em Atenas, três etapas importantes para o desenvolvimento da consciência da cidade a respeito de si mesma: consciência de participar da ação histórica e consciência da tomada de decisões em relação a suas próprias instituições. Nesse sentido, novos rituais foram estabelecidos, a fim de comemorar eventos históricos: depois da batalha de Maratona, por exemplo, incluiu-se no calendário religioso da cidade uma corrida tribal de tocha e criou-se um santuário, nas encostas da Acrópole, em honra do deus arcádico Pã, que aparecera ao corredor Filípides quando este retornava de sua fracassada missão em busca do auxílio espartano, tendo-lhe prometido ajuda na batalha (Heródoto VI, 105; Pausânias 1,I,4). Cónon construiu um santuário para Afrodite de Cnidos no Pireu, depois da vitória de Cnidos, em 394. Por sua vez, a criação dos jogos panatenaicos, em 566, marcou o início de uma série de novos festivais de competição; o concurso de tragédias, durante as Dionisíacas urbanas, foi instituído pelos tiranos; seguiram-se os concursos de comédia, por volta de 480. Hefesto e Prometeu também tinham corridas tribais de tocha em sua honra e, embora não se saiba quando foram instituídas, é certo que devem ter sofrido algumas modificações no final do século VI, quando Clístenes criou novas tribos. Instituiu-se ainda uma corrida em honra da deusa trácia Bêndis mais ou menos em 429 (I. G. I,3,36: cf. Pecírka $1966: 122-130$ ).

Ao lado desses festivais grandiosos e espetaculares, custeados e presididos pelo Estado e pelos magistrados eleitos, regulamentados por leis escritas e sem problemas de sentido para os participantes ou espectadores, no excitamento da competição e na alegria da vitória, alguns dos rituais mais antigos começaram a tornar-se problemáticos, especialmente os que eram organizados e custeados 
pelos clãs aristocráticos, cujo simbolismo não era mais entendido com clareza. De todos, o exemplo mais marcante é o ritual de Dipóleia ou Bufonia, o sacrifício do boi que Aristófanes (Nuvens 984-5) aponta como um dos costumes da cultura ateniense que a geração mais nova considerava ultrapassado, maçante e tolo. A Bufonia presumivelmente reencenaria a matança do primeiro boi ofertado em sacrifício: a vítima tinha de causar sua própria morte ao comer os cereais do altar, recusando-se assim os celebrantes a assumir qualquer culpa pelo sacrifício; a faca com que se abatia o animal era solenemente condenada e lançada ao mar, enquanto sua pele era empalhada, sendo colocada de pé novamente. Vários clãs aristocráticos menores participavam da cerimônia, cada um com o direito de indicar um dos celebrantes. E compreensível que os discípulos dos sofistas, habitantes da cidade e mais familiarizados com o boi em seu papel sacrificial do que em sua função na agricultura, não pudessem ver muito sentido em tudo isso. ${ }^{10}$

As comédias de Aristófanes, com freqüência baseadas em rituais religiosos, fornecem indícios a respeito do modo como diferentes cerimônias eram vistas pela população, a partir do próprio modo como o autor as trata. As Dionisíacas rurais, nos Acarnenses, e a Apatúria, na $P a z$, representam a tranquiilidade da vida rural, da qual os atenienses tinham sido privados pela guerra. Com efeito, mesmo a procissão até Elêusis deixara de ser realizada por causa da guerra (depois da captura de Deceléia), exceto em 407, quando Alcibíades a protegera com suas tropas. Pois bem, dois anos mais tarde, ao tomar a procissão de Elêusis como tema para as $R \tilde{a} s$, Aristófanes acrescenta um poderoso e emotivo argumento à recomendação de que Alcibíades fosse recebido de novo pela cidade.

10

Cf. Durand 1977; Detienne 1972; 105-8; $\mathrm{n}^{\circ} 5$ acima citado; e Gernet 1917 :164-7. Sobre os clãs: Toepffer $1889: 149-160$; Humphreys $1983 \mathrm{~b}$. Os historiadores da religião que acreditam existir um fluxo emocional na resposta ao sacrificio, seja em que periodo e em que meio social for, como Burkert (1972 b) e Girard (1972) tendem a fazer, acabam por subestimar diferenças essenciais no modo como esta emoção é sentida e trabalhada. Quando, na $P \alpha z$ (1017-1022), Aristófanes faz com que o cordeiro do sacrifício seja abatido fora da cena como uma vítima trágica, traça um paralelo que é implicitamente válido mas que, ao explicitar-se, se torna absurdo. Girard (1978, especialmente 61 e ss) reconhece o problema mas considera a reação judaico-cristã contra o sacrificio (que tem paralelos gregos) como um fenômeno singular sem precedentes e não como base para uma abordagem histórica das transformações religiosas. 
Por outro lado, contudo, as Tesmofórias, que constituem a base das Thesmophoriázousai, e os Skíra, nos quais se baseia, em certo sentido, a Assembléia de mulheres, parecem ter sido usados apenas em vista de seu potencial cômico. Trata-se de ritos dos quais só mulheres participavam, não tendo Aristófanes nem sua audiência, constituída predominantemente de homens, conhecimento direto do culto. ${ }^{11} \mathrm{O}$ sacrifício que, sabe-se, era executado pelas mulheres nos Tesmofórias (Detienne 1979) é parodiado na peça pelo sacrifício, feito por um homem intruso, de um "bebê" que acaba revelando-se um odre de vinho. As referências a Deméter e a Perséfone, as deusas celebradas na festa, são inespecíficas e confundem-se com uma canção e uma dança báquicas, bem como com invocações a Ārtemis, Hera, Hermes, Pã, às ninfas e a Atena. A principal característica desses rituais, para Aristófanes, não era a associação com a fertilidade, mas a inversão de papéis através da qual as mulheres passavam a ocupar lugares de proeminência, dando ocasião a um jogo de paródia e de troca dos papéis sexuais (cf. Zeitlin 1982).

Outras indicações sobre aspectos dos rituais que os atenienses instruídos não podiam mais levar a sério podem ser colhidas nas paródias com que os adolescentes da classe alta se entretinham e na descrição que Teofrasto faz do supersticioso (Caracteres 16) . Em fins do século V, Alcibíades e seus amigos parodiavam os mistérios eleusinos, enquanto um outro grupo de jovens andava pela cidade à noite, cortando todos os falos das imagens dos Hermes itifálicos que ficavam à porta das casas. Em ambos os

11

Não se tem certeza sobre se as mulheres assistiam ou não às peças (PickardCambridge $1968: 264-5)$. Os Skira eram um festival no qual os principais celebrantes da Acrópole deixavam a cidade em procissão até a antiga fronteira da Ática. As mulheres eram deixadas em posse da cidade (Burkert $1972 \mathrm{~b}: 161$ 8; não estou convencida, contudo, de que eram os Kérykes de Elêusis que vinham para a Acrópole dois dias depois, para celebrar os Dipolieia); há paralelos com os rituais e mitos associados com as mulheres de Lemnos (Burkert 1970). Quando, nas Elkklesiázousai, Aristófanes faz com que as mulheres de Atenas decidam, nos Skíra, vestir-se como homens e participar da Assembléia, a referência parece dirigir-se à inversão dos papéis masculinos e femininos e não ao travestismo efetivo do ritual (Gjerstad 1929; Jaccoby 1954:285-305, sobre F. G. H. 328 F 14-16; entretanto, ver Vidal-Naquet 1981: 166-7). Existe alguma evidência, embora não inteiramente conclusiva, de que, no fim do século IV e no período helenístico, os negócios públicos continuavam mesmo durante os dias dos Thesmophoria (Mikalson 1975) . 
casos, parece ser o uso de simbolismo sexual nos cultos o que provocava a zombaria. Um outro grupo de arruaceiros, que se dava o nome de os; Triballoí (os dissolutos), costumava recolher os testículos de porcos oferecidos a Hécate nas encruzilhadas para banquetear-se com eles (D, 54 Konon 14, 39). 12 Outro grupo semelhante se denomirıva Kakodaimonistai, "reverenciadores da má sorte", e escolhia deliberadamente dias de mau presságio para fazer suas reuniões (Lys., Frr. V, 2 Gernet).

Já o homem neuroticamente religioso de Teofrasto (ser um deisidaimon equivale a ser covarde diante dos deuses) faz de tudo presságio. Ele gasta seu tempo em ritos expiatórios e em consultas a adivinhos sobre o significado de seus sonhos. Vai aos sacerdotes órficos todo mês, a fim de purificar-se, acompanhado de seus filhos e de sua mulher ou, se ela estiver ocupada, da nutriz das crianças. ${ }^{13}$ Passa o quarto e o sétimo dia de cada mês a

\section{2}

$\mathrm{Na}$ medida em que os gregos tornavam-se mais conscientes das dificuldades em conciliar as concepções teológicas e materialistas do cosmo, os sacramentos naturais da comensalidade, da relação sexual -e da procriação, em vez de servirem como metáforas e analogias usadas para suprir a lacuna entre a experiência humana e a divina, tornaram-se obstáculos para a aceitação de mitos e rituais que os incorporavam. Os mitos foram alterados e reinterpretados pelos poetas (ci. Untersteiner 1972), mas era mais difícil manipular o ritual. Contudo, as paŕ́dias podem ser esclarecedoras. Persistiram redes de associação que ligavain pontos ambíguos e marginais da cultura e da sociedade, investidos, contudo, de novos significados: os Triballoi são um desses casos. Hécate era uma figura ambígua (cf. Teofrasto, Caracteres 16,7) e a idéia de uma deusa que comia testiculos de porcos devia, com certeza, ser perturbadora; os porcos eram animais marginais e as encruzilhadas eram espaços-limite. Hécate era Kourotróphos, aquela que nutria a juventude, e os adolescentes do sexo masculino tinham uma posição marginal na cidade; em seus banquetes, eles brincavam com os limites entre a vida pública e a vida privada (Humphreys 1983 a, 16-18), entre o masculino e o feminino e - como vemos aqui - entre o siugrado e o profano. Inconscientemente os Triballoi escolhiam modelos de associação mística que tornavam a paródia mais picante. 13

Ver Bolkestein 1929. Platão (Leis 907 d-910 e, cf. Bernays 1866 : 104) antecipa Teofrasto, associando ateísmo e deisidaimonía como os dois extremos entre os quais se encontra o neio termo de conduta conveniente com relação aos deuses, a eusebeía (Pötscher 1964:127-8). Xenofonte mostra Sócrates convertendo um átheos à religião filosófica em Memorabilia 1, IV. Os videntes, adivinhos e vendedores de oráculos da Atenas clássica são freqüentemente ridicularizados por Aristófanes; Platão investe ironicamente contra as pretensões de Éutifron, que se considerava agudo conhecedor de questões concernentes à piedade (o que o leva a acusar seu pai de homicídio) e à teologia moderna (etimologias racionalistas dos nomes dos deuses), no Eutifron e no Crátilo. Cf. a caracterização de Tirésias nas Bacantes de Eurípides (266 ss; Henrichs 1968). 
cuidar das imagens de culto hermafroditas. Este último procedimento é destacado de modo especial, em parte por ser considerado efeminado, mas também porque a idéia de divindades bissexuadas parecia então particularmente absurda. Já a purificação era ridicularizada em virtude dos meios mágicos que empregava: como é possivel que o banhar-se em sangue torne as pessoas puras? (Heráclito BSD-K).

Os encarregados dos cultos públicos da cidade reagiam a semelhantes críticas através de um duplo processo: davam proeminência crescente ao que parecia mais racional e procuravam desculpar o que parecia irracional. Há um gradual desvio de ênfase no culto, que não se pode datar com precisão mas que é claramente perceptivel no longo percurso desde as concepções mais arcaicas sobre os deuses, que acabam se tornando incompreensíveis, até a personificação de graças esperadas pelos homens: ${ }^{14}$ assim, um culto da Democracia foi instituído em 403 , após a expulsão do Conselho dos Trinta, bem como, em 374, criou-se um culto da Paz.

Através de uma inscrição do final do século IV, que registra o montante recebido com a venda do couro de animais sacrificados, pode-se ter idéia das principais cerimônias deste período pelo número de vítimas consumidas em cada uma delas. Zeus Salvador encabeça a lista: seu templo ficava no Pireu e era dividido com Atena Salvadora. Tal culto dificilmente poderia ser anterior às guerras médicas. O sacrificio se realizava no mesmo mês do antigo sacrifício de Dipóleia, em honra de Zeus Polieús, deus da pólis, ${ }^{15}$ denunciando uma reformulação do culto de Zeus na cidade. Em seguida vem a Teséia (instituída em 475, quando Címon trouxe de volta a Atenas os restos mortais de Teseu), na qual se celebrava simbolicamente a unidade da Âtica e seu poderio naval. Depois estão os sacrifícios a Asclépio, deus da cura. Seu culto foi introduzido em Atenas em 420/419 e, como era característico em seme-

14

Porventura o interesse dos atenienses no culto de Têmis e de Nêmesis em Rhamnous, no $\mathrm{V}$ século, representa um antigo estágio nesse processo de racionalização? Ver Nilson 1952; Hamdorf 1964.

15

Mommsen (1898:526-32) julga que ambos os festivais eram realizados no mesmo dia; a data dos Diisotéria não é conhecida com segurança (ver Mikalson $1975: 170-180$ ). 
lhantes adições tardias, o sacrifício foi incluído em festas já existentes: aos Eleusinia, em honra de Deméter e de Perséfone, e às Dionisíacas urbanas. As Dionisíacas urbanas, por sua vez, ocupam, em termos de importância, a mesma posição que o sacrifício à $\mathrm{Paz}$. Depois vem a festa de Zeus Olímpico, provavelmente fundada pelos Pisistrátidas, no VI século; a festa de Bêndis, intrcciuzida por volta de 429; o sacrifício à Democracia e um sacrifício feito pelos generais a Hermes, o Líder, que pode também ser associado com a restauração da democracia, em $403 ;^{16}$ a festa de Dioniso, no Pireu, ampliada pelo estadista Licurgo, por volta de 330; sacrifícios à Boa Sorte e um sacrifício ao deus líbio Amon, que dificilmente poderia ser antigo.

O culto das Panatenéias figura nessa lista numa posição sem destaque, pois os anos abrangidos não incluem a celebração das Grandes Panatenéias, estando incompletas as inscrições relativas às Panatenéias menores. Sabe-se, todavia, a partir de uma outra inscrição do mesmo período (I. G. ii $^{2} 334$ ), que a Panatenéia menor, anual, incluía nessa época sacrifícios a Atenâ Nike, deusa da vitória, e a Atenâ Hygieía, deusa da saúde. Ambos os cultos devem ter surgido na época de Péricles (cf. Boersma 1970, XIV-XV).

Assim, através da adição de novas festas e de novas invocações dos velhos deuses, o calendário religioso da cidade ganhou um aspecto mais racional, sendo os ritos públicos direcionados no sentido de se tornarem comemoração de grandes eventos do passado ou ocasião de súplica em favor de bênçãos futuras. Quando elementos menos "racionais" sobreviviam, eram desculpados como importados - como, de fato, era a festa de Bêndis e se julgava ser o culto de Dioniso - ou protegidos de críticas pelo sigilo, como acontecia com o rito central dos mistérios e com o ritual executado por mulheres nos Tesmofória e nos Skíra.

Mulheres e crianças constituíam o elo entie o caráter público do ritual e o crescente esforço para localizá-lo na esfera privada. As crianças e os jovens, em particuiar, parecem ter assumido, a

16

Hermes Hegemônio é mencionado no Plutos de Aristófanes (1159), mas atualmente apenas podemos conjecturar que poderia ser uma referência tópica a um novo culto. Uma relação mais completa dos cultos públicos em Atenas, na época de Licurgo, encontra-se em Humphreys 1985. 
partir do quarto século, um papel mais proeminente no culto público. A reorganização do ritual e das finanças das Panatenéias por Licurgo inclui uma provisão de jóias a serem usadas por cem Kanephóroi, moças "carregadoras de cestos", oriundas da classe alta, cujo desempenho em tal função começou a ser comemorado por suas famílias, através de inscrições. Há também monumentos do quarto século comemorativos da iniciação de jovens nos mistérios eleusinos, na qualidade de "filhos do lar urbano" _ "pais aph' hestías" - representando todos os cidadãos. ${ }^{17}$

Parece também provável ter sido na época de Licurgo que a assistência aos rituais e a participação nas procissões religiosas passaram a ser deveres dos ephéboi, quando estavam prestando servico militar, dos 18 aos 20 anos (cf. Humphreys 1985). Estes se tornaram uma espécie de representação ideal do conjunto dos cidadãos que acompanhava as procissões, subjugando e conduzindo os touros sacrificiais e fazendo exibições militares e atléticas durante as festas. Ao vê-los, os pais podiam sentir orgulho e satisfação por estarem seus filhos sendo instruídos nas virtudes cívicas e imbuídos do sentido da história da cidade. Há um paralelo evidente entre este uso dos jovens no ritual e o papel das jovens heroínas e heróis, como Meneceu, que se sacrificam pela comunidade nas tragédias de Eurípides: em ambos os casos, trata-se daqueles que não estão ainda completamente envolvidos na vida pública, podendo mais facilmente representá-la em seus ideais.

\section{7}

Kanephóros, I. G., 11.2 3457; sobre seu número ver Brelich 1969; sobre a Lisistrata de Aristófanes 641-7, ver Vidal-Naquet $1981: 197-8$. Pâ̂s aph' hestías: Clinton 1974:98-114 (cf. Kourouniotis 1923: fig. 8; Mklonas 1961 : 203 e fig. 80). Uma menção é restaurada de modo plausível em I. G., i3 6 C 25, e certa em Clinton 1980, frag. d 5 (metade do IV século; a restauração de uma outra referência ao aph' hestías em a 41 não segue o contexto). Não é contudo claro se os mais antigos paîdes foram crianças ou adolescentes (ainda que eu não esteja sugerindo que os cultos de mistérios, com seus diversos graus de iniciação, pudessem ser confundidos com a iniciação como um rito de passagem para a adolescência). Parece-me haver um crescimento gradual de interesse, no período clássico, pela concepção e pintura de deuses como crianças que é, por volta do fim do IV século e no período helenístico, acompanhado de (ainda que não sistematicamente associado com) um aumento do uso de crianças em idade pré-púbere, bem como de adolescentes, no ritual. Mas a extensão e a cronologia dessa tendência não é clara. Estaria presumivelmente relacionada, em parte, com a crescente tendência em considerar o mito adequado apenas para os primeiros estágios da educação das crianças. 
Outra alternativa era usar homens mais idosos em funções religiosas proeminentes. A comissão enviada a Delfos em solene embaixada, provavelmente em 326/325 (Lewis 1955), foi chefiada por dois sexagenários, Licurgo e Nicérato, este último bisneto do general Nícias, que vivera no quinto século. O orador Demades e o historiador Fanodemos, também membros da comissão, não seriam muito mais jovens. Mais ainda, o mesmo grupo se incumbiu da realização da festa e dos jogos no santuário do herói da saúde, em Oropos, que Filipe da Macedônia havia colocado sob o controle de Atenas após a batalha de Queronéia. Licurgo e Demades eram políticos ativos; Nicérato e Fanodemos, cada um a seu modo, agiam como elos vivos entre o presente e o passado. ${ }^{1.8}$

Embora Licurgo pareça ter-se considerado um segundo Péricles, não tendo feito esforço para mudar as instituições básicas do estado democrático, há alguns elos entre seu programa e o proposto por Platão nas Leis. Os nomophylakes de Platão deveriam ter mais de 50 anos ao assumir sua função, continuando a exercê-la até os 70 (755 a 4-b 2) ; sacerdotes e sacerdotisas deveriam ter mais de 60 anos $(759 \mathrm{~d})$, mantendo-se na função por um ano (cf. Aristóteles, Politica, 1329 a 27-34). Por outro lado, seria função dos rituais religiosos misturar as diversas classes $(759 \mathrm{~b})$, provocando ampla convivência social, particularmente com o objetivo de possibilitar aos rapazes e moças a oportunidade de se conhecerem uns aos outros antes de escolherem os futuros cônjuges (771 d-772 a) . Aqui, de novo, são os jovens e os velhos que são destacados para representar a comunidade no contexto religioso.

Do mesmo modo, pode-se descobrir elos entre o programa de Licurgo e a representação da religião em Eurípides. Já mencionei

18

As principais figuras do ritual não eram muito trabalhadas para manter seu status na cidade e suas relações com os deuses, mas representavam valores que pareciam ter afinidades com o ritual. De modo semelhante, os direitos outorgados de refeição no Pritaneu não implicavam no privilégio de aumento de poder, como no período arcaico - quando fazer a refeição na mesa do arconte implicava tomar assento no centro dos negócios da pólis - mas significava antes que as pessoas distinguidas com tal honra podiam servir de icones vivos das glórias passadas da cidade (cf. Schmitt-Pantel 1980), duplicatás em carne e osso das estátuas da ágora, um equivalente cívico permanente da representação dos ancestrais mortos que se observa nos rituais funerários da aristocracia romana (cf. o uso de substitutos vivos para os reis mortos entre os Merina de Madagascar; Bloch 1981). 
a altruística devoção à comunidade, presente em jovens heroínas e no jovem Meneceu, quando se sacrificam para assegurar a vitória (Aélion 1983 II : 113-124). Tal devoção chegou mesmo a confundir os que viam Eurípides como cético, satírico e racionalista. Acontece, todavia, que ele parece querer mostrar, com muita freqüência, o contraste existente entre o sórdido mundo de intrigas dos homens ligados à política e às questões públicas e um mundo mais puro e mais pacífico, associado com as mulheres e os jovens, com o campo agreste e com lugares sagrados, longe do alarido da cidade. ${ }^{19}$ Frequientemente são as odes cantadas que, em meio aos horrores da ação trágica, alçam brevemente a audiência a um outro plano. No Héracles, imediatamente antes de o herói ser tomado pela loucura e matar sua mulher e seus filhos, o coro canta uma ode em louvor da juventude (637 ss.): se os deuses fossem sábios, segundo os padrões humanos de sabedoria, concederiam aos homens bons uma segunda juventude e duas vidas, de modo que eles fossem separados do resto da humanidade como estrelas que brilham entre nuvens. Mas, do modo como as coisas se dão, o único meio de celebrar as realizações dos homens é unir inseparavelmente a vitória, dom das Graças, à música, aos cantos e à dança triunfal de moças às pcrtas do templo.

Nas Troianas, a partida de Astiánax ao encontro da morte é seguida de uma ode na qual o coro lamenta ainda as desgraças de Tróia mas também faz alusão às imagens cheias de paz da ilha de Salamina, onde reinava Telamon, à feliz juventude de Ganimedes em Tróia, e à resplandecente deusa Aurora, apaixonada por Titono. Algumas vezes é o aparecimento de um deus ex-machina, no fim da peça, que conclui a ação, reafirmando os valores religiosos, como acontece, por exemplo, na Electra, com o surgimento de Castor e Pólux, as estrelas que guiam os marinheiros. A função do deus ex-machina não é justificar retrospectivamente as ações míticas representadas nem permitir a um dramaturgo desastrado escapar de uma situação insolúvel, mas antes manifestar os elos da ação

19

Meus comentários sobre Eurípides devem muito ao livro de Helene Foley (Ritual Irony 1985), cujo manuscrito tive o privilégio de ler, considerando-o extremamente clarividente e estimulante - embora ela não possa ser responsabilizada pelos rumos a que suas idéias me levaram. 
com o passado mítico (o qual sobrevive na Ātica, sendo familiar para a audiência) e ligar, de uma maneira nova, a tragédia ao ritual.

As peças de Eurípides ajudam a entender a crescente importância do papel atribuído aos jovens no ritual público e o modo como os grandes eventos do passado histórico ou mítico servem como símbolos da unidade da cidade e de sua gloriosa reputação. Mas elas ilustram tambérn como a experiência religiosa foi sendo associada com a vida privada e com contextos não políticos, mais do que com os rituais do Estado. A "tensão entre o transcendental e o mundano" (Eisenstadt 1982) apresenta-se nelas de modo muito claro e, se algumas vezes personagens e ações que estabelecem a conexão trágica entre esses dois planos trazem salvação, como nos casos de sacrifícios em favor da comunidade, em outras situações provocam apenas destruição (Hipólito, Bacantes). Lugares totalmente devotados ao culto, sem vida urbana normal, têm especial poder religioso: como Licurgo se interessasse muito por Delfos e pelo remoto santuário de Anfiarao, Eurípides situa a ação do ion em Delfos e faz Andrômaca buscar refúgio num santuário fora da cidade. O Ẽdipo, de Sófocles, morre num bosque sagrado em Colono, tendo sido rejeitado em vida pela pólis Como se pode perceber, as imagens do mundo natural e do mundo mítico se entrelaçam. Para os gregos antigos (como para alguns poetas gregos modernos), as paisagens da natureza estavam povoadas por forças divinas $\mathrm{e}$ semi-divinas e balizadas por marcos míticos (cf. Borgeaud 1979; Veyne 1983). O imaginário dionisíaco, que associa mulheres à possessão religiosa, às montanhas desertas e às paisagens agrestes, aparece em muitas peças, não apenas nas Bacantes.

Mas as mulheres representam ainda a paz, em oposição à guerra, a continuidade, mais que o conflito. Na Hécuba, a história do saque de Tróia é relatada pelo coro, segundo a perspectiva de uma jovem esposa cujo marido acabara de comemorar a partida dos gregos: ela estava justamente preparando-se para deitar, penteando os cabelos defronte do espelho, quando ouviu o ataque começar. Alceste sacrifica sua própria vida para preservar a "casa" de seu esposo, seu ô̂kos; como na Antígona, de Sófocles, é uma mulher que age heroicamente em defesa dos valores da vida privada (Humphreys 1983, c.4). São as mulheres que lamentam os mortos 
e se lembram de que há outras, na pátria do inimigo, que choram igualmente (Hécuba 650-6). $\overline{\mathrm{E}}$ freqüente serem mulheres as que zelam pelas sepulturas, conforme os desenhos em lécitos do quinto século.

A lei contra a colocação de monumentos esculpidos em sepulturas, estabelecida quase no fim do sexto século, perdeu sua validade durante a Guerra do Peloponeso. As famílias passaram a erigir monumentos privados mesmo para aqueles que haviam morrido na guerra e que tinham sido sepultados em túmulos públicos no cemitério do Cerâmico (I. G. $i i^{2}$ 6217). As estelas funerárias, com efeito, mostram as famílias unidas: homens e mulheres num eterno mundo privado (Humphreys 1983, c.5). Também as práticas religiosas do homem supersticioso de Teofrasto centram-se em seus negócios domésticos e em suas inquietações pessoais. $\overline{\mathrm{E}}$ um procedimento semelhante que Platão tem em mente quando bane todos os cultos privados de sua cidade cretense (Leis 909-910 e), enfatizando particularmente o perigo de sua exploração por "experts" fraudulentos.

\section{Lógica e inspiração}

Os supersticiosos sentiam-se tranqüilizados pelo tom erudito e paracientífico dos "experts" religiosos da época clássica: os sacerdotes mendicantes e os adivinhos - diz Platão, com desdém, na República (364 b-365a) - vão às casas dos ricos prometendo purif̂icação das culpas, meios de prejudicar os inimigos usando a magia, além de felicidade nesta vida e na próxima, tudo com base na citação de um monte de livros escritos por Museu e Orfeu, filhos da Lua e das Musas.

O desenvolvimento mais marcante das ciências do irracional magia, astrologia e demais teorias ocultistas - ocorre no período helenístico e a importação de "sabedoria alienígena" da Pérsia, do Egito e da Babilônia contribuiu para o crescimento de seu prestígio (Momigliano 1975; Dodds 1951 : 245-7; sobre a contribuição grega, Long 1982). Mas, uma vez formulada a crítica da advinhação e da magia como irracionais, formas de racionalização equivalentes começam a agir. $\overline{\mathrm{E}}$ preciso distinguir, mais detalhadamente do que fez Dodds, o processo de racionalização dos objetivos 
dos que nele se envolviam e dos procedimentos de verificação por eles empregados. De um lado, observa-se uma dialética entre racionalidade e irracionalidade, na qual cada esforço para fixar os limites do pensamento racional produz renovadas tentativas no sentido de racionalizar o irracional; por outro lado, existe um conflito entre a investigação crítica e os atrativos de uma autoridade incapaz de questionar suas próprias suposições. ${ }^{20}$

A racionalização não era, de qualquer modo, o único meio pelo qual se podia defender o valor de idéias que os filósofos ridicularizavam como irracionais. Havia também uma defesa do irracional como tal, do valor de uma linguagem "poética" elevada e de várias formas de "loucura divina": Platão, no Fedro (265 b, cf. 244 a-245 a), faz referência aos transes proféticos, à inspiração poética, à possessão dionisíaca e ao amor (cf. Brisson 1974; Demócrito, B1718 D.-K) .

Como observei acima, a idéia das divindades como forças psicológicas encontrava-se já em Homero (cf. Vernant 1966). A introdução do culto de Pã, o arcádio deus do "pânico", em Atenas, depois da batalha de Maratona, e sua difusão por toda Grécia não representavam uma maneira totalmente nova de conceber os deuses. De qualquer modo, no sucesso desse culto - em que se fundiam a idéia de um poder divino entendido como uma força psicológica, a relação da divindade com espaços remotos, ermos e montanhosos, e a autoridade especial de práticas de culto tidas como antigas e primitivas - pode-se perceber várias das motivações principais do pensamento religioso clássico (cf. Borgeaud 1979).

Parece desenvolver-se uma concepção mais apurada da entrega a estados psicológicos paranormais como forma de culto religioso. A gruta de Pã, em Vari, na Ātica, apresenta uma série de inscrições votivas do século V, feitas por Arquedemo de Tera (I. G. ${ }^{2}$ 784-8), uma das quais o trata de "Archédemos ho nymphóleptos" - que se poderia traduzir por "Arquedemo, o lunático". O caso mais

20

Ver Werber $1968: 196-200$, sobre a racionalização formal da adivinhação e de outras práticas mágicas. Uma doutrina é sistematicamente elaborada, mas essa crescente sofisticação não é acompanhada por um pensamento critico concernente à metodologia e aos processos de verificação. Cf. Gascoigne 1983, para alguns destacáveis exemplos contemporâneos. 
claro de possessão religiosa associada com áreas remotas e desertas ocorre, sem dúvida, no culto de Dioniso. Platão, nas Leis (815 b-d), evita mesmo regulamentar os ritos báquicos e as danças nas quais se imitam Ninfas, Pãs, Silenos e Sátiros, definindo-os como "não pertencentes à cidade", "ou politikón”. $\overline{\mathrm{E}}$ significativo, com efeito, que os principais participantes desses ritos orgiásticos pareçam ter sido mulheres. A representação das mênades, feita por Eurípides nas Bacantes e por outros testemunhos das fontes de que dispomos, se deveria provavelmente mais à fantasia do que aos fatos, mas isso não importa de nosso ponto de vista. O deveras significativo é que os homens atenienses - os pintores de vasos, os dramaturgos e os que frequientavam o teatro - fossem profunda e ambiguamente atraídos pela idéia de virem a ser totalmente possuídos por um deus ao participarem de ritos em sua homenagem, escapando assim completamente da estrutura da pólis e dos limites de identidade cotidianos. Como acontece com Penteu na peça citada, tanto desejavam passar por essa experiência como a receavam. Ao acreditar que tais ritos fossem executados apenas por mulheres, em lugares onde nenhum homem pudesse presenciá-los, procuravam tornar a experiência mais aceitável para os critérios gregos da decência e, ao mesmo tempo, mais plausível. Essa crença, no entanto, tornava suas fantasias mais excitantes e fazia mais assustadora ainda a idéia da loucura dionisíaca, a qual envolveria uma perda radical da personalidade em que mesmo a identidade sexual desapareceria. ${ }^{21}$

\footnotetext{
21

Ver Just 1975; Henrichs 1978 e 1982; Padel 1983. A influência freudiana tornou moda ver o retrato de Penteu, em Eurípides, como um estudo de caso de um homem com tendências transexuais, reveladas em sua reação à idéia de vestir roupas de mulher. Isto é, creio, uma inversão do interesse de Euripides: reduzir a experiência religiosa, na peça, a sexo não faz sentido. Ele seguramente usa o sexo - ou melhor, o gênero - como um instrumento para falar sobre a experiência religiosa. Para um homem grego, abandonar-se ao êxtase era quase tornar-se mulher - instável, emotiva, aberta à penetração. Todavia, essa idéia exerce algum fascinio (cf. Girard 1978:421). essencial, desse ponto de vista, que os sentimentos ambíguos de Penteu com relação à identidade de gênero funcionam como uma metáfora, a qual não deveria ser apresentada nem percebida como um caso psiquiátrico, estando a audiência apta a relacioná-la com seus próprios sentimentos. Pode ser relevado que Penteu é apresentado como um jovem solteiro - não muito distante, assim, de uma idade na qual ser coquete e desempenhar um papel sexual feminino eram coisas aceitas socialmente (neanias: Bacantes 274, 974).
} 
As mênades não só eram mulheres mas teriam também trazido seus ritos da Trácia. E que tudo que parecia estranho e indecoroso no ritual religioso era desculpado pela atribuição de uma origem numa região bárbara ou numa parte do território grego essencialmente atrasada e "aborígene", como a Arcádia ou Creta (Borgeaud 1979).

A origem estrangeira de um deus podia desculpar quaisquer peculiaridades do ritual executado em sua honra: aos deuses, afinal, tinha-se de prestar o tipo de devoção que eles esperavam. Nesse contexto, novos cultos estrangeiros foram importados e, em alguns casos, incluídos oficialmente no calendário religioso da cidade, como os da deusa Trácia Bêndis, por volta de 429, da Grande Mãe (associada com Creta e Āsia), de Adônis (Detienne 1972), de Ísis, de Afrodite (Astarté) de Cítio, em Chipre, e de Amon. Foi o próprio Licurgo quem propôs que se desse permissão aos comerciantes de Cítio para comprar um terreno, a fim de erguer um templo a sua Afrodite nativa, citando como precedente uma autorização semelhante dada aos adoradores de Ísis (I. G. ii $^{2} 337$ ). Se, por um lado, tais propostas refletem a crescente parcela de imigrantes na população de Atenas, indicam também um gosto cada vez maior pelo exótico no ritual religioso, o sentimento de que apenas o que fosse bárbaro, estranho e completamente diferente da vida ordinária poderia ser verdadeiramente religioso.

Há ainda outro indício do crescente senso de separação entre religião e atividades profanas: a tendência cada vez mais forte em se considerar as atividades religiosas como uma questão de escolha e não como parte de uma divisão do tempo em períodos seculares e sagrados admitida por todos. A partir disso pôde-se desenvolver também a idéia de uma existência completamente devotada à religião, como retratada por Eurípides no Ion e - em certo sentido - no Hipólito.

Também na poesia pode-se, de vez em quando, perceber apelos direcionados para uma deliberada valorização do irracional. Desde suas origens, a poesia grega abrangeu uma extensa gama de estilos, que ia do dialeto literário formalizado na épica ao uso direto da linguagem coloquial, como se pode constatar em várias passagens de Sólon, Arquíloco ou Alceu. Antes do fim do sexto século, a 
poesia era a única forma de linguagem preservada pela escrita, com exceção de algumas frases breves e um pequeno número de leis e tratados. O desenvolvimento da prosa escrita como meio de expressão de uma visão de munđo individual (em oposição às decisões coletivas) levantou questõe concernentes à relação entre prosa e poesia que até então não existiam. Não se deve, contudo, sobrestimar a importância desse fato. $\overrightarrow{\mathrm{E}}$ uma questão delicada distinguir entre o desenvolvimento da consciência de si como indivíduo, própria dos poetas, e a tendência crescente de todos os intelectuais da época de dignificar seu status e sua missão pela reivindicação de um tipo de sabedoria (sophía) especial (cf. Humphreys 1975, com a bibliografia aí citada, além de Svenbro 1976).

Assim, um estilo oracular aparece tanto em Píndaro quanto em Heráclito. No entanto, os próprios atenienses presenciam, no $\mathrm{V}$ século, o surgimento do estilo "ditirâmbico", restrito à poesia e caracterizado por longas palavras de exótica ressonância, por onomatopéias, por imagens forçadas, por reviravoltas enigmáticas e densas nas frases. ${ }^{22} \mathrm{Na}$ época de Aristófanes e de Eurípides esse estilo "bardo" já soava antiquado (Nuvens 984-5) e pretensioso, embora tenha contribuído significativamente para o estabelecimento do papel do poeta na geração de Píndaro e de Ésquilo.

Apesar de o estilo ditirâmbico estar associado principalmente à poesia oral, como seu nome indica, foi à tragédia que se incorporaram outros aspectos do uso deliberado do irracional na poesia, sendo nela explorados por mais tempo. Buscavam-se e legitimavam-se efeitos exóticos - por exemplo, ao se fazer com que estrangeiros emitissem sons estranhos (como nos Persas), ou através de personagens possuídos, loucos ou endemoniados (como Cassandra, Orestes, as Fúrias). Quanto mais irracional, mais poético. $\overrightarrow{\mathrm{E}}$ claro que muitas dessas passagens eram cantadas, não faladas, e a música,

Murray $1940: 59-68$. Stanford $1942: 38-40$, sobre a conexão entre Esquilo e os textos orficos, embora não possamos dizer em qual direção se dá a influência. Rosenmeyer 1982, cap. 4, que vai contra a tendência de exagerar esse elemento no estilo de Esquilo. Nesta obra pode-se ver algumas das fontes da tradição classicizante relativa à grandeza poética (semnótes), a qual herdamos, embora não se possa projetar a totalidade de seu desenvolvimento além de princípios do $\mathrm{V}$ século a. C. 
certamente, realçava seu efeito. Embora apreciasse igualmente os efeitos musicais exóticos, o gosto de Eurípides em cunhar novas palavras seria diferente do de Ésquilo, além de estar ele mais interessado em representar diferentes espécies de loucura e em experimentar novos gêneros de música. ${ }^{23}$

\section{Conclusão: da ruptura ao diálogo}

A internalização do diálogo entre o racional e o irracional na cultura grega clássica torna-se particularmente evidente em Platão, o filósofo que considerava a matemática a mais alta forma do pensamento humano, mas não podia expressar suas idéias filosóficas senão pela invenção de seus próprios mitos (cf. Segal 1978), o escritor de gênio que desejava banir a poesia do processo educacional, o fundador da Academia que acabou se tornando o santo padroeiro dos místicos neoplatônicos. Com efeito, ninguém mais que ele teve consciência tão profunda da tensão que se tinha estabelecido entre as questões e os métodos das novas disciplinas do pensamento racional e as outras questões e outros meios de exploração do universo postos de lado, os quais permaneciam sem resposta.

Uma das maiores contribuições da cultura grega para o tema aqui proposto foi, a meu ver, a de ter trazido à luz o contínuo debate que está implícito, mas talvez não suficientemente enfatizado, na idéia de uma tensão entre os níveis mundano e transcendental da realidade. Mesmo quando a divisão do trabalho entre diferentes grupos da elite intelectual parece ser bem sucedida no sentido de evitar o conflito, pode-se ainda encontrar algum nível de interação no discurso. Mas, na Grécia, o que começa como polêmica daqueles que conscientemente se sentem os porta-vozes de novas idéias, contra as crenças tradicionais do resto da sociedade, se transforma logo em debate internalizado com que não pode deixar de se confrontar nenhum pensador sério. A irrupção da nova visão de mundo não foi uma vitória fácil, mas o início de um longo diálogo em que "religião", "ciência" e "filosofia" começaram a adquirir alguns de seus contornos modernos.

23

Bárbaros: Aélion 1983, II, cap. 6; loucura, Ibid., cap. 


\section{BIBLIOGRAFTA}

AELION, R. Euripide héritier d'B́schyle I-II. Paris, Les Belles Lettres, 1983. BERNAYS, J. Theophrastos' Schrift über Frömmigkeit. Berlin, Hertz, 1866. BLOCH, M. Tombs and States. In: HUMPHREYS, S. C. \& KING, H., eds., Mortality and Immortality. London, Academic, $1981: 137-147$.

BOERSMA, J. S. Athenian Building Policy from 561/0 to $405 / 4$ B. C. Groningen, Wolters and Noordhoff, 1970.

BOLKESTEIN, H. Theophrastus' Charakter der Deisidaimon als religionsgeschichtliche Urkunde. Giessen, Töpelmann, 1929.

BORGEAUD, P. Recherches sur le dieu Pan. Rome, Institut Suisse, 1979.

BORDIEU, P. Outline of a Theory of Practice. Cambridge, University Press, 1977.

BRELICH, A. Paides a Parthenoi. Rome, Ateneo, 1969.

BREMMER, J. Literacy and the origins and limitations of Greek atheism. In: BOEFT, J. \& KESSELS, A., eds., Actus: Studies in Honour of H.L.W. Nelson. Utrecht, Instituut voor Klassieke Talen, $1982: 43-55$.

BRISSON, L. Du bon usage du dérèglement. In: VERNANT, J.-P., Divination et rationalité. Paris, Seuil, $1974: 220-248$.

BURKERT, W. Jason, Hypsipyle and new fire at Lemnos. Classical Quarterly $20: 1-16,1970$.

BURKERT, W. Lore and Science in Early Pythagoreanism. Cambridge, Mass., Harvard University Press, 1972 (a).

BURKERT, W. Homo Necans. Interpretationen altgriechischer Opferriten und Mythen. Berlin, De Gruyter, 1972(b) .

BURKERT, W. Craft versus sect: the problem of Orphics and Pythagoreans as alternative groups. In: MEYER \& SANDERS, $1982: 1-22$.

CLINTON, K. The Sacred Officials of the Eleusinian Mysteries. Transactions of the American Philosophical Society, N. S. 64(3), 1974.

CLINTON, K. A law in the City Eleusinion concerning the Mysteries. Hesperia $49: 258-288,1980$.

DETIENNE, M. Les jardins d'Adonis. Paris, Gallimard, 1972.

DETIENNE, M. Dionysos mis à mort. Paris, Gallimard, 1977.

DETIENNE, M. Violentes 'eugénies' en pleines Thesmophories: des femmes couvertes de sang. In: DETIENNE, M. \& VERNANT, J.-P., eds., Le cuisine du sacrifice en pays grec. Paris, Gallimard, $1979: 183214$.

DETIENNE, M. L'invention de la mythologie. Paris, Gallimard, 1981.

DEUBNER, L. Attische F'este. Berlin, Akademie-Verlag, 1956.

DIHLE, A. Das Satyrspiel Sisyphos. Hermes $105: 28-42,1977$.

DODDS, E. R. The Greeks and the Irrational. Berkeley, University of California, 1951.

DODDS, E. R. The Ancient Concept of Progress and other essays. Oxford, Clarendon Press, 1973.

DOVER, K.J. The freedom of the intellectual in Greek society. Talanta $7: 24-54,1975$.

DURAND, J.-L. Le rituel du meurtre du boeuf laboureur et les mythes du premier sacrifice animal en Attique. In: GENTILI, B. \&' PAIONE, G. eds., $n$ mito greco. Rome, Ateneo e Bizarri, $1977: 121-134$. 
EISENSTADT, S. N. The axial age: the emergence of transcendental visions and the rise of clerics. European Journal of Sociology $23: 294-314,1982$.

FOLEY, Helene P. Ritual Irony: Poetry and Sacrifice in Euripides. Ithaca, Cornell University Press, 1985.

GASCOIGNE, B. The Quest for the Golden Hare. London, Jonathan Cape, 1983.

GERNET, L. Platon, Lois livre IX, traduction et commentaire. Paris, Leroux, 1917.

GIRARD, R. La violence et le sacré. Paris, Grasset, 1972.

GIRARD, R. Des choses cachées depuis la fondation du monde. Paris, Grasset, 1978 .

GJERSTAD, E. Das attische Fest der Skira. Archiv für Religionswissenschaft $27: 189-240,1929$.

HAMDORF, F. W. Griechische Kultpersonifikationen der vorhellenistischen Zeit. Mainz, Von Zabern, 1964.

HENRICHS, A. Die «Erdmutter» Demeter. Zeitschrift für Papyrologie und Epigraphik $3: 111-112,1968$.

HENRICHS, A. Two doxographical notes: Democritus and Prodicus on religion. Harvard Studies in Classical Philology. $79: 93-123,1975$.

HENRICHS, A. Greek maenadism from Olympias to Messalina. Harvard Studies in Classical Philology 82 : 121-160, 1978.

HENRICHS, A. Changing Dionysiac identities. In: MEYER \& SANDERS $1982: 137-160$.

HUMPHREYS, S. C. «Transcendence» and intellectual roles: the ancient Greek case. Daedalus 104(2): 91-118, 1975 (= Humphreys $1978: 209-241$ ).

HUMPHREYS, S. C. Anthropology and the Greeks. London, Routledge \& Kegan Paul, 1978.

HUMPHREYS, S. C. The Family, Homen and Death: comparative studies. London, Routledge \& Kegan Paul, 1983(a).

HUMPHREYS, S. C. Fustel de Coulanges and the Greek genos. Sociologia del diritto $8: 35-44,1983(\mathrm{~b})$.

HUMPHREYS, S. C. Lycurgus: an Athenian aristocrat. In: EADIE, J. \& OB.ER, J. eds., Essays presented to Chester Starr, 1985.

JACOBY, F. Die Fragmente der griechrischen Historiker, III b Suplemente, I. Leiden, Brill, 1954 .

JUST, R. Conceptions of women in classical Athens, Journal of the Anthropological Society of Oxford 6(1):153-170, 1975.

KIRK, G.S. Some methodological pitfalls in the study of Greek sacrifice (in particular). In: Le sacrifice dans l'antiquité, Entretiens Hardt $27: 41-80$, 1981.

KOUROUNIOTIS, K. Eleusiniaka. Archaiologikon Deltion 8 : 155-174, 1923.

LEWIS, D. M. Notes on Attic Inscriptions, II. Annual of the British School at Athens $50: 1-36,1955$.

LIEBESCHUETZ, J. H. W. G. Continuity and Change in Roman Religion. Oxford, Clarendon Press, 1979.

LLOYD, G. E. R. Polarity and Analogy. Cambridge, University Press, 1966.

LLOYD, G. E. R. Magic, Reason and Experience. Cambridge, University Press, 1979.

LONG, A. A. Astrology: arguments pro and contra. In: BARNES, J. ed., Science and Speculation. Cambridge, University Press, 1982 : 165-192.

CLASSICA, Belo Horizonte, $3: 13-44,1990$ 
MEIJER, A. A. Philosophers, intellectuals and religion in Hellas. In: VERSNEL, $1981: 216-264$.

METTE, H.-J. Die Fragmente der Tragödien des Aischylos. Berlin, AkademieVerlag, 1959 .

MEYER, F. \& SANDERS, E. P., eds. Jewish and Christian Self-definition. Vol. 3: Self-definition in the Graeco-Roman world. London, S. C. M. Press, 1982.

MUKALSON, J.D. The Sacred and Civil Calendar of the Athenian Year. Princeton, University Press, 1975.

MOMIGLIANO, A. Freedom of speech in antiquity; Impiety in the classical world. In: Dictionary of the History of Ideas, New York, Scribner, $1973: 252-263 ; 564-567$.

MOMIGLIANO, A. Alien Wisdom, The Limits of Hellenization. Cambridge, University Press, 1975.

MOMMSEN, A. Feste der Stadt Athen im Altertum. Leipzig, Teubner, 1898. MURRAY, G. Five Stages of Greek Religion. Oxford, Clarendon Press, 1925.

MURRAY, G. Aeschylus: the creator of tragedy. Oxford, Clarendon Press, 1940 .

MYLONAS, G. E. Eleusis and the Eleusinian Mysteries. Princeton, University Press, 1961.

NILSSON, M.P. Kultische Personifikationen. Eranos $50: 31-40,1952$.

PADEL, R. Women: model for possession by Greek daemons. In: CAMERON, A. \& KUHRT, A. eds., Images of Women in Antiquity. London, Duckworth, $1923: 3-19$.

PECIRKA, J. The Formula for the Grant of Enktesis in Attic Inscriptions. Prague, Acta Universitatis Carolinae, Philosophica et Historica Monographia 15, 1966.

PICKARD-CAMBRIDGE, A. The Dramatic Festivals of Athens. Oxford, Clarendon Press, 1968.

PöTSCHER, W., ed. Theophrastus, Peri Eusebias. Leiden, Brill, 1964.

RICHARDSON, N. J. Homeric professors in the age of the sophists. Proceedings of the Cambridge Philological Society 201 (N. S. 21): 65-81, 1975.

ROSENMEYER, T. G. The Art of Aeschylus. Berkely, University of California, 1982.

SABATUCCI, D. Saggio sul misticismo greco. Roma, Ateneo, 1965.

SCHMITT-PANTEL, P. Le repas au prytanée et a la tholos dans l'Athènes classique. Sitésis, trophé, misthos: réflexions sur le mode de nourriture démocratique. Archeologia e storia antica, Annali del Seminario di Studi del Mondo Classico (Napoli) 2 : 55-68, 1980.

SEGAL, C. «The myth was saved»: reflections on Homer and the mythology of Plato's Republic. Hermes 106 : 315-336, 1978.

SMITH, P.J. On the Hymn to Zeus in Aeschylus Agamemnon. Chico, Scholars Press, 1980.

SVENBRO, J. La parole et le marbre. Aux origines de la poétique grecque. Lund, Studentlitteratur, 1976.

TOEPFFER, J. Attische Genealogie. Berlin, Weidmann, 1889.

UNTERSTEINER, M. La fisiognomia del mito. Firenze, Nuova Italia, 1972.

VERNANT, J.-P. La société des dieux. In: La Naissance des dieux, Paris, Editions Rationalistes, 1966 : 55-78. 
VERNANT, J.-P. Mythe et société en Grèce ancienne. Paris, Maspero, 1974. VERSNEL, H.S., ed. Faith, Hope and Worship. Aspects of religious mentality in the ancient world. Leiden, Brill, 1981.

VEYNE, P. Les Grecs ont-ils cru à leurs mythes? Paris, Seuil, 1983.

VIDAL-NAQUET, P. Le chasseur noir. Formes de pensée et formes de société dans le monde grec. Paris, Maspero, 1981.

WEBER, Max The Religion of China. New York, Free Press, 1968.

WEST, M. L. Thre Presocratic Cosmologies. Classical Quarterly, N. S. 13 : 154176, 1963.

WEST, M. L. The Orphic Poems. Oxford, Clarendon Press, 1983(a) .

WEST, M. L. Tragica VI : 12, Aeschylus' Lycurgeia. Bulletin of the Institute of Classical Studies $30: 63-71,1983(\mathrm{~b})$.

WOTKE, F. Pais (Mysterien). In: PAULY-WISSOWA, Realencyclopädie, 36.1, cols. 2428-2435, 1942.

ZEITLIN, F. Travesties of gender and genre in Aristophanes' Thesmophoriazousae. In: FOLEY, H.P. ed., Reflections of Women in Antiquity. New York, Gordon \& Breach, 1982 : 169-217.

Conferência proferida em 14 de setembro de 1984, na Faculdade de Filosofia e Ciências Humanas da Universidade Federal de Minas Gerais, em promoção conjunta do Departamento de Letras Clássicas e do Setor de Estética do Mestrado em Filosofia da mesma Universidade. Tradução de Lúcia Las Casas e Jacyntho Lins Brandão. 